\title{
Behaviour of Precast Concrete Beam-to-Column Connection with SHS Hidden Corbel Subjected to Monotonic Load
}

\author{
Jen Hua Ling ${ }^{1, *}$, Jee Hock Lim², Ahmad Baharuddin Abd. Rahman ${ }^{3}$ \\ ${ }^{1}$ School of Engineering and Technology, University College of Technology Sarawak, Sarawak, MALAYSIA \\ 96000 Sibu, Sarawak, Malaysia \\ 2 Department of Civil Engineering, Universiti Tunku Abdul Rahman, Selangor, MALAYSIA \\ 43000 Selangor, Malaysia \\ ${ }^{3}$ Department of Structures and Materials, School of Civil Engineering, Universiti Teknologi Malaysia, Johor, MALAYSIA \\ 81310 Skudai, Johor Darul Ta'zim, Malaysia \\ *Corresponding authors: lingjenhua@ucts.edu.my
}

SUBMITTED 7 January 2021 REVISED 29 January 2021 ACCEPTED 4 February 2021

\begin{abstract}
Beam-to-column connection is the most critical part of a precast concrete (PC) that governs the integrity of the entire structure, hence its characteristics need to be determined for safe applications in the construction industry. Therefore, this study developed a beam-to-column connection with square hollow section (SHS) hidden corbel. A full-scale test was conducted on eleven Tsubframe specimens with various configurations used to investigate the behaviour of the connection under an incremental static load. It was further evaluated using the beam-line method to determine the moment-rotation response and the mechanical properties. Furthermore, this research analyzed the parametric response, the load resisting mechanism, and the feasibility of the connection for PC structures. Due to extensive usage of steel elements, the PC connection gave a higher ultimate strength than the reinforced concrete (RC). Its moment resistance was largely contributed by the hidden corbel embedded in the beam and column, increasing with the column and beam's embedded length. The grout infill prevented the lateral deformation of the hidden corbel and hence strengthened the connection. Due to the low bending resistance of the steel endplate, the PC connection possessed a low stiffness, which led to a larger rotation deformation than the RC connection, and a low design strength. This could be overcome by modifying the shape of the endplate for a higher second moment of inertia in resisting bending. The PC connection was classified as semi-rigid and partial-strength, and only specimen PC-3 was considered feasible for PC structures.
\end{abstract}

KEYWORDS Beam-to-column connection; Precast; Hidden corbel; Beam-line method; Full-scale test.

(c) The Author(s) 2021. This article is distributed under a Creative Commons Attribution-ShareAlike 4.0 International license.

\section{INTRODUCTION}

Precast concrete (PC) is one of the construction methods popularly used in Malaysia. The building elements are prefabricated in factories under controlled environments with good quality assurance before being transported to construction sites for installation. This permits the rapid erection of PC structures with less energy and labour consumption, including low risk of occupational safety and health (Zheng et al., 2018; Lu et al., 2019; Lin \& Zhao, 2020).

The joint between the building elements is normally the weakest part of a PC structure (Choi et al., 2013). It governs the behaviour and integrity of the entire structure. The beam-tocolumn connection in PC is a joint between a beam and a column. It is designed to have the ability to transfer loads from a member to another, such as shear, moment, axial, torsion, etc. The connection needs to be reliable, for structural stability, and preferably easy-to-install for speedy construction.

However, the connections for a wide variety of designs possess unique characteristics. Therefore, it is important to realize the behaviour of a connection for this purpose. Although PC elements are made of concrete, the connections demonstrate the characteristics of steel joints. This is due to the extensive use of steel components to transfer loads and facilitate installations. 
For the low deformability of concrete, the PC connection normally fails with excessive cracks before the failure of the steel elements. Hence, determining the properties of the connection solely based on the steel components is likely overestimating its performance. Therefore, the beam-line method is used to determine the properties of a PC connection (Elliott, 2002). These are further used to classify the connection in respect to the Eurocode 3 (BS EN 1993-18:2005).

The characteristics of a newly developed beamto-column connection can be determined using the full-scale destructive test (Jaspart, 1996; Lim, 2014). In this study, a beam-to-column connection with a hidden corbel made of square hollow section (SHS) was developed for nonseismic applications. An experimental test was carried out to acquire the structural behaviour as well as classify the connection. The parametric response and the load resisting mechanism of the connection were also analyzed. Furthermore, the feasibility of the connection in PC structures was evaluated.

\section{METHODS}

\subsection{Specimen Details}

Eleven full-scale $\mathrm{T}$-subframe specimens were fabricated and tested under incremental monotonic load. This included 2 control (i.e. RC0 and PC0) and 9 test specimens (i.e. PC1 to PC9), each of which comprised of a square column and rectangular beam, designed with respect to the common sizes and reinforcements used in the local construction industry (Figure 1 and Table 1). The load was applied on the beam at a distance of $1375 \mathrm{~mm}$ from the column face.

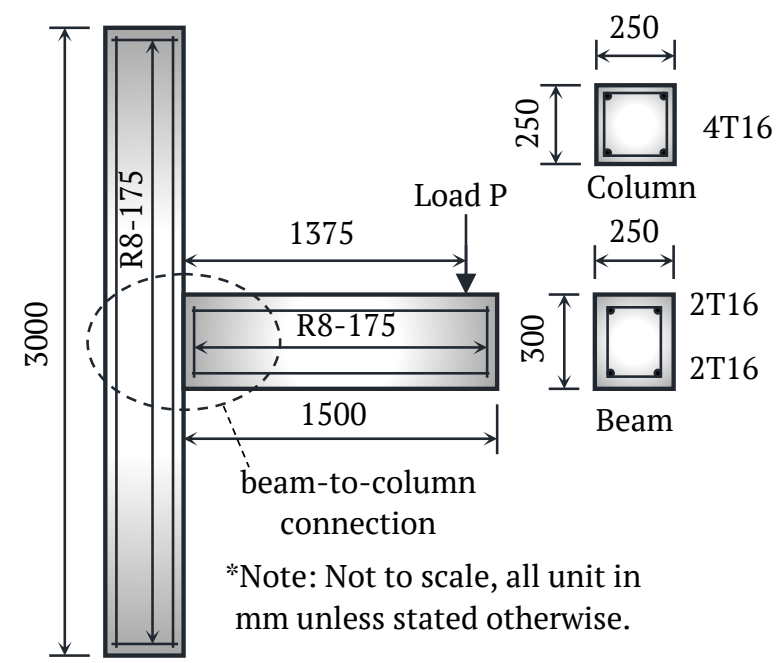

Figure 1. Details of specimen

The configuration of the specimens are described as follows

a) Specimen RC0 represented a reinforced concrete (RC) joint (Figure 2(a)). The concrete was monolithically cast without a cold joint (Figure 3). The steel bars of the beam were embedded in the column at full anchorage length.

b) Specimen PCO resembled a PC connection without an SHS hidden corbel (Figure 2(b)). The steel bars in the beam were welded on a $20 \mathrm{~mm}$ thick steel endplate of grade S275. In addition, the endplate was further bolted to the column.

c) Specimens PC1 to PC9 were PC connections with SHS hidden corbels (Figure 2(c)). The design was identical to PC0 except for the 2 SHSs of different sizes embedded in the beam. Meanwhile, during installation, the smaller SHS was slid and inserted into the column before the grout was poured into the void (Figure 4).

Table 1. Dimension of specimen

\begin{tabular}{lll}
\hline & Beam & Column \\
\hline Dimension & $250 \mathrm{~mm}$ x $300 \mathrm{~mm}$ x $1500 \mathrm{~mm}$ & $250 \mathrm{~mm}$ x 250 mm x 3000 mm \\
Reinforcements & Top and bottom bars, high yield strength & High yield strength steel bars, 4T16 $\left(f_{s y}=460\right.$ \\
& steel bars 2T16 $\left(f_{s y}=460 \mathrm{~N} / \mathrm{mm}^{2}\right)$ & $\left.\mathrm{N} / \mathrm{mm}^{2}\right)$ \\
Shear links & Mild steel bars, R8-175 $\left(f_{s y}=250 \mathrm{~N} / \mathrm{mm}^{2}\right)$ & Mild steel bars, R8-175 $\left(f_{s y}=250 \mathrm{~N} / \mathrm{mm}^{2}\right)$ \\
Concrete cover & $41 \mathrm{~mm}$ & $25 \mathrm{~mm}$ \\
\hline
\end{tabular}




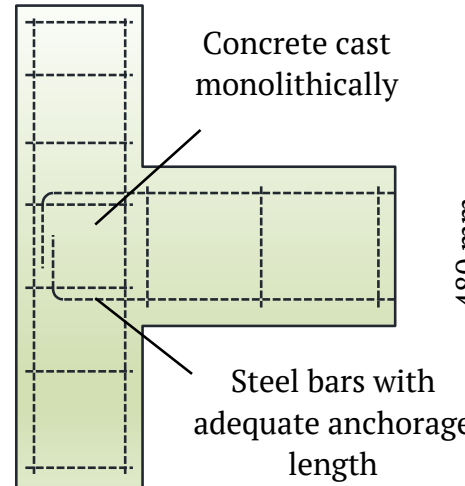

(a) RCO (Control)

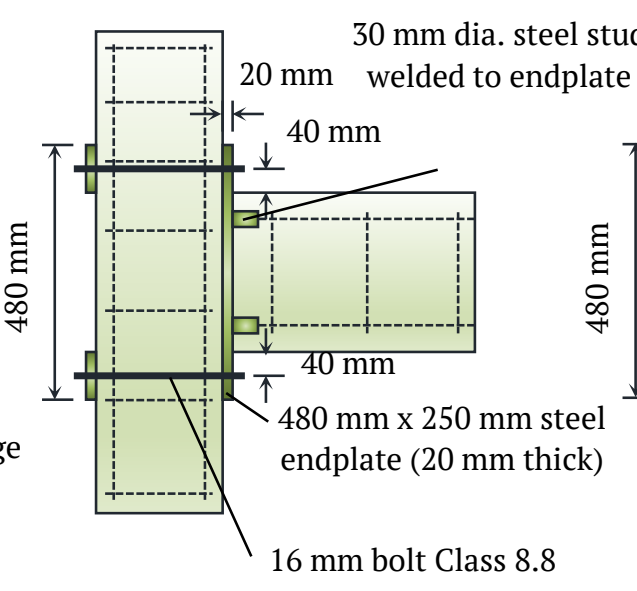

(b) PCO (Control)

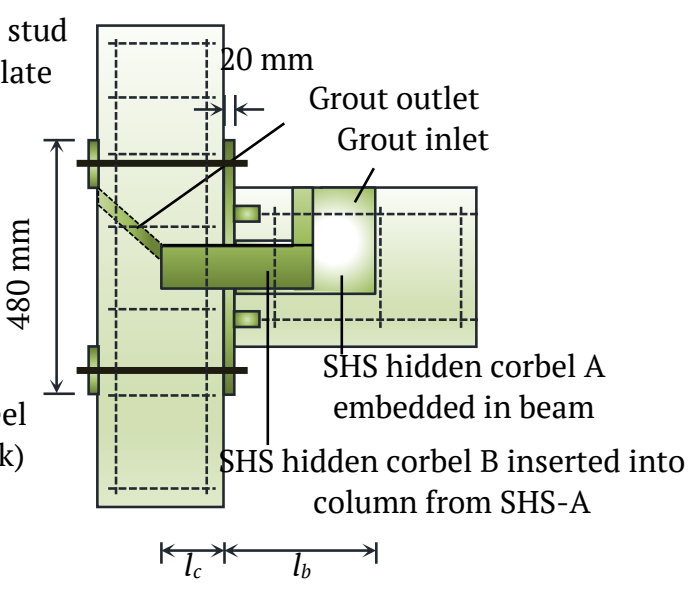

(c) PC1-9

Figure 2. Design of specimens

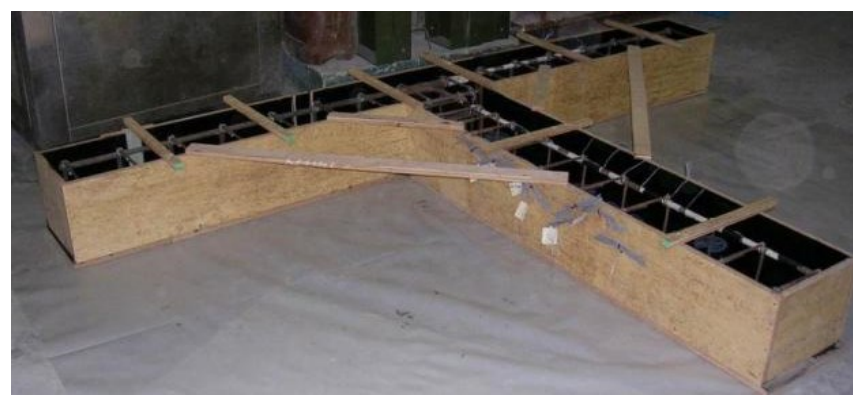

(a) Reinforcement and formworks

Figure 3. Preparation of specimen RCO

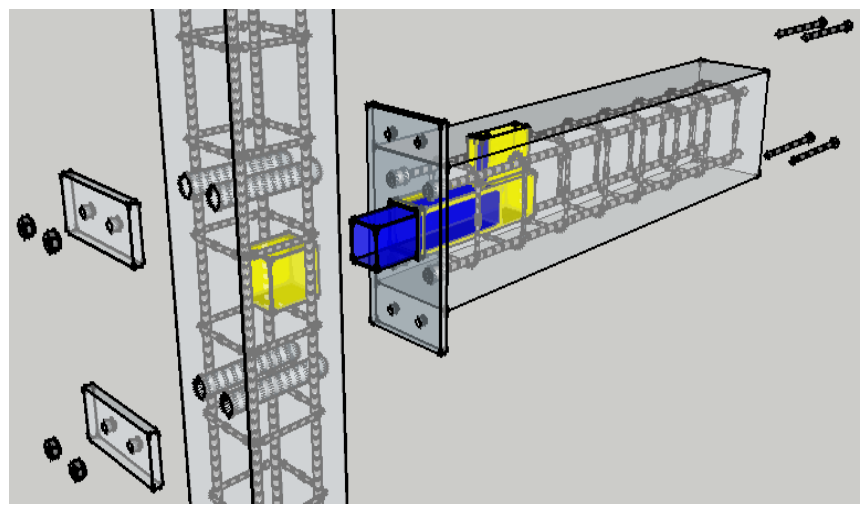

Figure 4. Installation of the connection

The details of the connections are shown in Table

2. The parameters studied included

a) Effects of PC beam-to-column connection (RC0 vs PC0-9)

b) Effects of SHS hidden corbel (PC0 vs PC1-9)

c) Effects of the hidden corbel size (PC1-3)

d) Effects of the embedded length of hidden corbel in column (PC3-5)

e) Effects of the embedded length of hidden corbel in beam (PC3, 6, and 7)

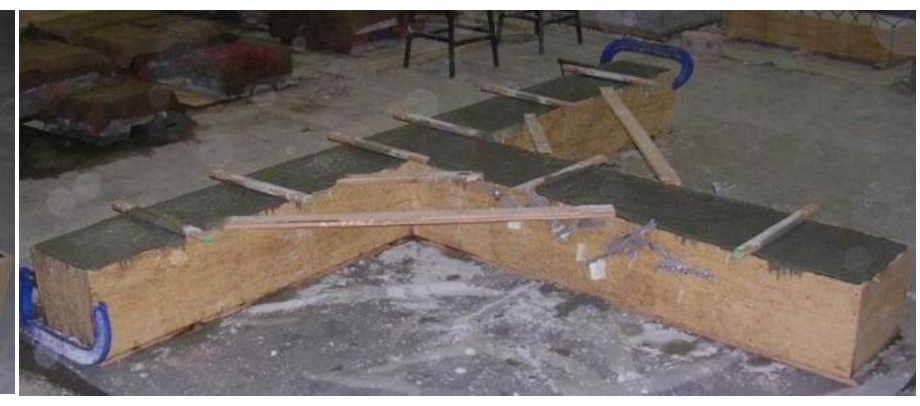

(b) Monolithic casting

f) Effects of grout in hidden corbel (PC3, 8, and 9)

The specimens were horizontally cast with grade 40 ready-mixed concrete in the laboratory. The design slump was relatively $50 \mathrm{~mm}$ to $100 \mathrm{~mm}$ while the maximum aggregate size was $20 \mathrm{~mm}$. The specimens were cured under moisture with wet jute sacks for 7 days before installation on the $28^{\text {th }}$ day.

Subsequently, high strength and non-shrink grout (Brand: Sika-215) of grade 70 was mixed into a pourable state during installation. The proportion of the mixture comprised 4 litres of water per $25 \mathrm{~kg}$ of grout power. The grout was poured into the hidden corbel through its inlet until an overflow was detected at the outlet. The compressive strength of the grout was closely monitored until that which was intended was achieved before the specimens were tested. 


\subsection{Test Setup}

Steel frames were assembled in the laboratory to test the specimens. The support frame held the column in position while the load frame induced vertical load onto the beam (Figures 5(a) and (b)). The column was restrained from horizontal displacement and moment rotation by inserting its ends in the grip buckets.

A hydraulic cylinder (Brand: Enerpac, capacity: $250 \mathrm{kN}$ ) was used to generate the load acting on the beam at a distance of $1375 \mathrm{~mm}$ from the column face. A load cell (Brand: TML, capacity: $100 \mathrm{kN}$ ) was used to measure the weight on the beam. In addition, twelve linear variable displacement transducers (LVDT) (Brand: TML) and 2 inclinometers (Brand: AccuStar) were used to measure the displacement and rotation of the column and beam of the specimens (Figure 5(c)). Furthermore, six LVDTs $\left(\mathrm{H}_{1}\right.$ to $\left.\mathrm{H}_{6}\right)$ were used to measure the horizontal displacement of the column. Meanwhile, another six $\left(\mathrm{V}_{1}\right.$ to $\left.\mathrm{V}_{6}\right)$ were used to determine the vertical displacement of the beam. All the measuring devices were connected to a logger (Brand: TML, 30 channels) for data acquisition.

Once the setup was completed, all readings were initialized to zero. The load was progressively increased at a rate of approximately $2.5 \mathrm{kN}$ per reading taken. The load response and the crack propagation of the specimen were monitored throughout the test.

Table 2. Details of specimen

\begin{tabular}{|c|c|c|c|c|c|}
\hline Specimen & $\begin{array}{l}\text { Embedded length of } \\
\text { hidden corbel in } \\
\text { column, } l_{c}(\mathrm{~mm})\end{array}$ & $\begin{array}{l}\text { Embedded length of } \\
\text { corbel in beam, } l_{b} \\
(\mathrm{~mm})\end{array}$ & $\begin{array}{l}\text { SHS hidden } \\
\text { corbel A size } \\
(\mathrm{mm})\end{array}$ & $\begin{array}{l}\text { SHS hidden } \\
\text { corbel B size } \\
(\mathrm{mm})\end{array}$ & $\begin{array}{l}\text { Grout } \\
\text { strength, } f_{u, g} \\
\left(\mathrm{~N} / \mathrm{mm}^{2}\right)\end{array}$ \\
\hline $\mathrm{RC0}$ & \multicolumn{5}{|c|}{ Monolithic reinforced concrete connection } \\
\hline PCO & \multicolumn{5}{|c|}{ Precast concrete connection without SHS hidden corbel } \\
\hline PC1 & 125 & 300 & 50.8 & 38.1 & 40 \\
\hline PC2 & 125 & 300 & 76.2 & 63.5 & 40 \\
\hline PC3 & 125 & 300 & 101.6 & 88.9 & 40 \\
\hline PC4 & 75 & 300 & 101.6 & 88.9 & 40 \\
\hline PC5 & 175 & 300 & 101.6 & 88.9 & 40 \\
\hline PC6 & 125 & 200 & 101.6 & 88.9 & 40 \\
\hline PC7 & 125 & 400 & 101.6 & 88.9 & 40 \\
\hline PC8 & 125 & 300 & 101.6 & 88.9 & 20 \\
\hline PC9 & 125 & 300 & 101.6 & 88.9 & NIL \\
\hline
\end{tabular}

* Thickness of all SHSs was $3 \mathrm{~mm}$ 


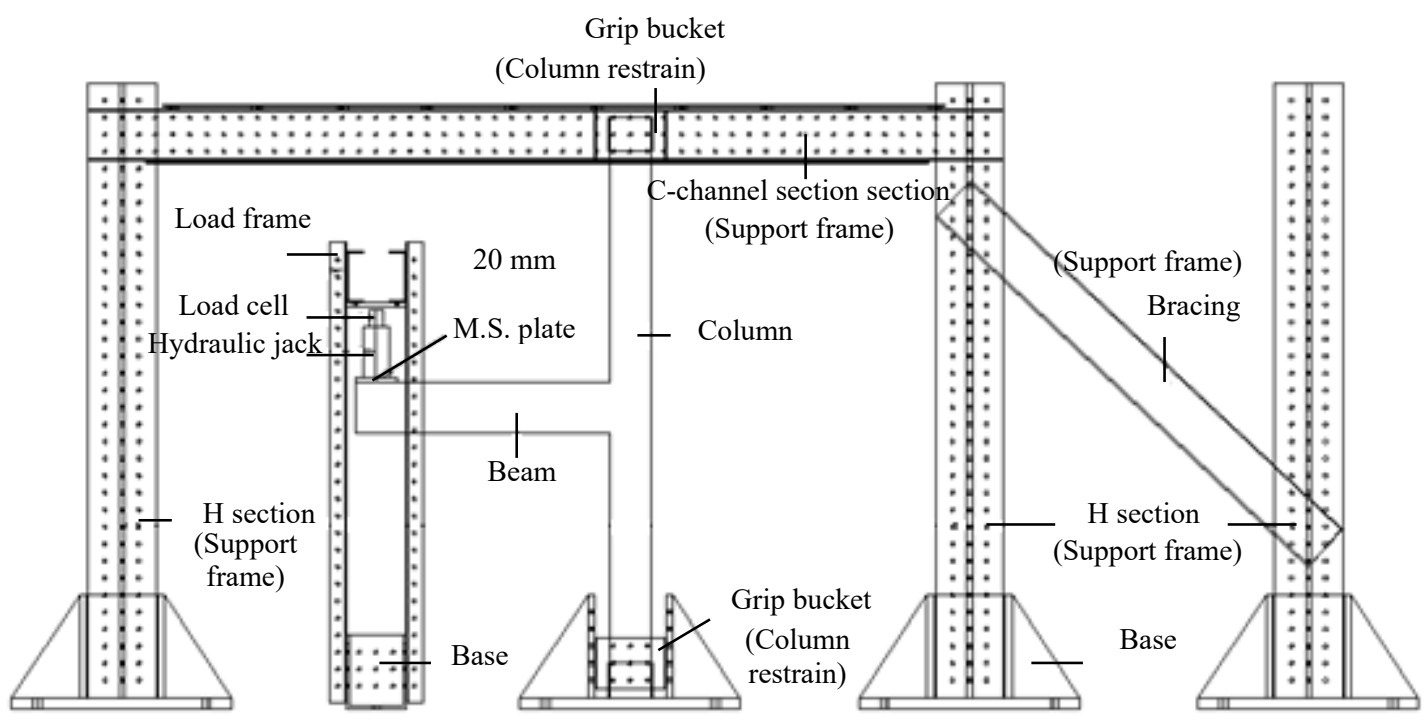

(a) Loading frames

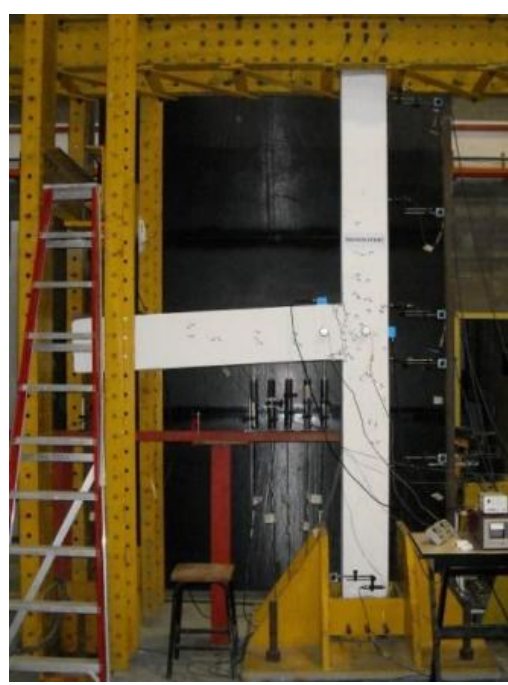

(b) Test setup

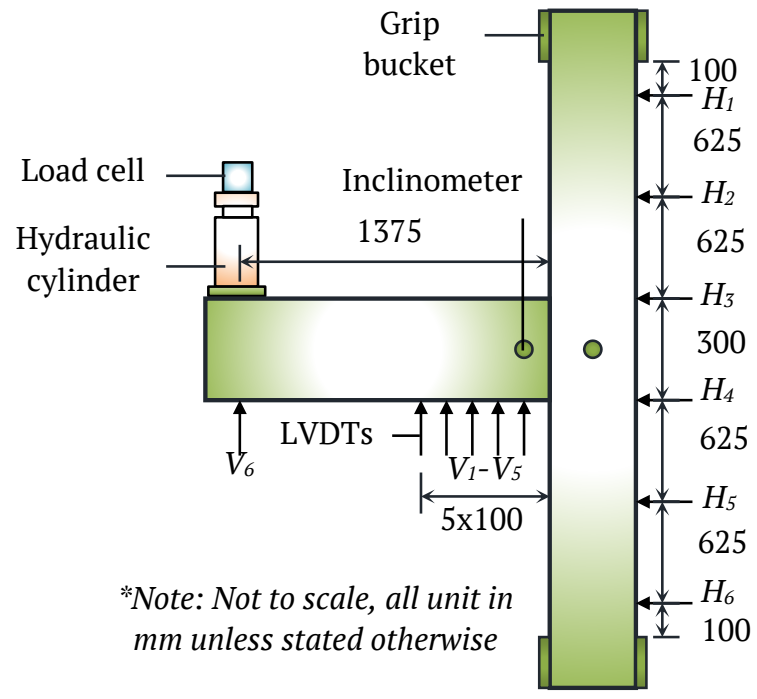

(c) Instrumentation

Figure 5. Test setup and instrumentation

\section{RESULTS AND DISCUSSIONS}

\subsection{Material Properties}

The properties of the materials used to fabricate the specimens are shown in Tables 3 and 4 . The compressive strength of the concrete and grout were quite consistent. In addition, they were also close to their intended strengths of $40 \mathrm{~N} / \mathrm{mm}^{2}$. The yield strengths of the steel components were all higher than their nominal strengths of 460 $\mathrm{N} / \mathrm{mm}^{2}$ and $250 \mathrm{~N} / \mathrm{mm}^{2}$, respectively. Practically, the quality of materials was considered acceptable.

\subsection{Test Results}

The results of the specimens are shown in Table 5. The first crack load was determined immediately a crack was detected on the surface of the specimen. The ultimate load had the highest load recorded throughout the test.

The data were further recomputed into the moment-rotation $(M-\phi)$ response using Equations (1) and (2), as shown in Table 6 and Figure 6.

$M_{i}=P_{i} L$ 
where $M_{i}$ is the moment acting on the connection at different load levels $(\mathrm{kNm}), P_{i}$ is the load acting on the beam $(\mathrm{kN})$, and $L$ is the distance of the point load from the connection face (m). $\phi_{i}=\phi_{b, i}-\phi_{c, i}$

where $\phi_{b, i}$ and $\phi_{c, i}$ are the moment rotation of the beam and column respectively (milli-rad).

Table 3. Compressive strength of concrete and grout of the specimens

\begin{tabular}{lll}
\hline Specimens & Compressive strength of concrete, $f_{c, u}\left(\mathrm{~N} / \mathrm{mm}^{2}\right)$ & Compressive strength of grout, $f_{g, u}\left(\mathrm{~N} / \mathrm{mm}^{2}\right)$ \\
\hline RC0 & 36.6 & - \\
PC0 & 38.0 & - \\
PC1 & 38.6 & 40.1 \\
PC2 & 38.7 & 40.2 \\
PC3 & 39.3 & 40.0 \\
PC4 & 39.6 & 40.4 \\
PC5 & 39.2 & 39.9 \\
PC6 & 41.3 & 40.4 \\
PC7 & 39.0 & 39.4 \\
PC8 & 40.1 & 20.0 \\
PC9 & 39.8 & - \\
\hline
\end{tabular}

*Average values of 2 and 3 cube samples for concrete and grout, respectively.

Table 4. Tensile strength of steel components of the specimens

\begin{tabular}{lllll}
\hline Specimen & $\begin{array}{l}\text { Yield Strength, } \\
f_{y}\left(\mathrm{~N} / \mathrm{mm}^{2}\right)\end{array}$ & $\begin{array}{l}\text { Ultimate strength, } \\
f_{u}\left(\mathrm{~N} / \mathrm{mm}^{2}\right)\end{array}$ & $\begin{array}{l}\text { Young Modulus, } \\
E\left(\mathrm{kN} / \mathrm{mm}^{2}\right)\end{array}$ & $\begin{array}{l}\text { Strain Elongation } \\
(\%)\end{array}$ \\
\hline Steel bars T16 & 525 & 611 & 210 & 14.47 \\
Steel bars R8 & 450 & 506 & 234 & 14.85 \\
$20 \mathrm{~mm}$ thick steel endplate & 303 & 384 & 229 & 19.67 \\
$38.1 \mathrm{~mm}$ SHS & 321 & 358 & 202 & 7.64 \\
$50.8 \mathrm{~mm}$ SHS & 278 & 338 & 202 & 11.99 \\
$63.5 \mathrm{~mm}$ SHS & 319 & 399 & 202 & 9.39 \\
$76.2 \mathrm{~mm}$ SHS & 303 & 351 & 204 & 9.79 \\
$88.9 \mathrm{~mm}$ SHS & 326 & 375 & 200 & 11.63 \\
$101.6 \mathrm{~mm}$ SHS & 346 & 389 & 202 & 9.70 \\
\hline
\end{tabular}

*Average values of 3 steel samples

Table 5. Test results

\begin{tabular}{|c|c|c|c|c|c|c|c|c|}
\hline \multirow[b]{2}{*}{ Specimen } & \multicolumn{4}{|c|}{ First Crack } & \multicolumn{4}{|c|}{ Ultimate state } \\
\hline & $\begin{array}{l}\text { Load, } \\
P_{i c} \\
(\mathrm{kN}) \\
\end{array}$ & $\begin{array}{l}\text { Vertical } \\
\text { displacement, } \\
\delta_{\text {ic }}(\mathrm{mm}) \\
\end{array}$ & $\begin{array}{l}\text { Beam } \\
\text { rotation, } \\
\phi_{b, i c}\left(^{\circ}\right) \\
\end{array}$ & $\begin{array}{l}\text { Column } \\
\text { rotation, } \\
\phi_{c, i c}\left(^{\circ}\right) \\
\end{array}$ & $\begin{array}{l}\text { Load, } P_{u} \\
(\mathrm{kN})\end{array}$ & $\begin{array}{l}\text { Vertical } \\
\text { displacement, } \\
\delta_{u}(\mathrm{~mm}) \\
\end{array}$ & $\begin{array}{l}\text { Beam } \\
\text { rotation, } \\
\phi_{b, u}\left({ }^{\circ}\right) \\
\end{array}$ & $\begin{array}{l}\text { Column } \\
\text { rotation, } \\
\phi_{c, u}\left({ }^{\circ}\right)\end{array}$ \\
\hline RC0 & 7.5 & 2.0 & 0.06 & 0.03 & 39.1 & 50.0 & 1.69 & 0.44 \\
\hline PC0 & 8.3 & 3.1 & 0.10 & 0.01 & 41.3 & 80.1 & 2.9 & 0.27 \\
\hline PC1 & 8.2 & 4.1 & 0.16 & 0.03 & 42.4 & 76.1 & 2.28 & 0.36 \\
\hline PC2 & 10.0 & 4.4 & 0.15 & 0.03 & 45.7 & 96.0 & 2.67 & 0.39 \\
\hline PC3 & 9.7 & 3.7 & 0.09 & 0.03 & 47.3 & 102.2 & 2.28 & 0.58 \\
\hline PC4 & 5.7 & 3.6 & 0.13 & 0.02 & 46.3 & 116.2 & 3.49 & 0.48 \\
\hline PC5 & 6.5 & 2.0 & 0.05 & 0.02 & 49.5 & 86.0 & 1.84 & 0.43 \\
\hline PC6 & 9.8 & 4.0 & 0.12 & 0.02 & 42.1 & 72.0 & 1.82 & 0.25 \\
\hline PC7 & 10.2 & 3.8 & 0.10 & 0.04 & 49.8 & 60.0 & 1.97 & 0.85 \\
\hline PC8 & 10.6 & 3.8 & 0.09 & 0.03 & 46.8 & 94.1 & 2.18 & 0.57 \\
\hline PC9 & 8.3 & 5.9 & 0.20 & 0.03 & 44.7 & 106.1 & 3.55 & 0.43 \\
\hline
\end{tabular}


Table 6. Moment and rotation of the specimen

\begin{tabular}{|c|c|c|c|c|c|c|}
\hline \multirow[b]{2}{*}{ Specimen } & \multicolumn{3}{|c|}{ First crack } & \multicolumn{3}{|c|}{ Ultimate state } \\
\hline & $\begin{array}{l}\text { Moment, } M_{i c} \\
(\mathrm{kNm})\end{array}$ & $\begin{array}{l}\text { Rotation, } \phi_{i c} \\
\left(10^{-3} \mathrm{rad}\right)\end{array}$ & $\begin{array}{l}\text { Stiffness, } S_{i c} \\
\left(\mathrm{kNm} / 10^{-3} \mathrm{rad}\right)\end{array}$ & $\begin{array}{l}\text { Moment, } M_{u} \\
(\mathrm{kNm})\end{array}$ & $\begin{array}{l}\text { Rotation, } \phi_{u} \\
\left(10^{-3} \mathrm{rad}\right)\end{array}$ & $\begin{array}{l}\text { Stiffness, } S_{u} \\
\left(\mathrm{kNm} / 10^{-3} \mathrm{rad}\right)\end{array}$ \\
\hline Equation & (1) & (2) & (3) & (1) & (2) & (3) \\
\hline RC0 & 10.3 & 0.5 & 20.6 & 53.8 & 21.8 & 2.5 \\
\hline PC0 & 11.4 & 1.6 & 7.1 & 56.8 & 45.9 & 1.2 \\
\hline PC1 & 11.3 & 2.3 & 4.9 & 58.3 & 33.5 & 1.7 \\
\hline PC2 & 13.8 & 2.1 & 6.6 & 62.8 & 39.8 & 1.6 \\
\hline PC3 & 13.3 & 0.9 & 14.8 & 65.0 & 29.7 & 2.2 \\
\hline PC4 & 7.8 & 1.8 & 4.3 & 63.7 & 52.5 & 1.2 \\
\hline PC5 & 8.9 & 0.5 & 17.8 & 68.1 & 24.6 & 2.8 \\
\hline PC6 & 13.5 & 1.6 & 8.4 & 57.9 & 27.5 & 2.1 \\
\hline PC7 & 14.0 & 0.7 & 20.0 & 68.5 & 19.5 & 3.5 \\
\hline PC8 & 14.6 & 1.1 & 13.3 & 64.4 & 28.1 & 2.3 \\
\hline PC9 & 11.4 & 2.8 & 4.1 & 61.5 & 54.5 & 1.1 \\
\hline
\end{tabular}

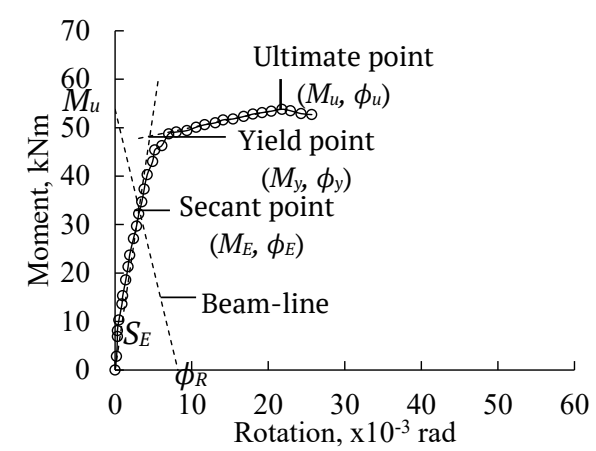

(a) Specimen RCO

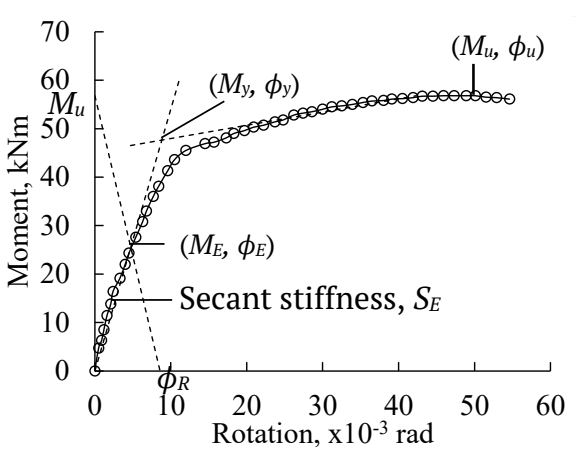

(b) Specimen PCO

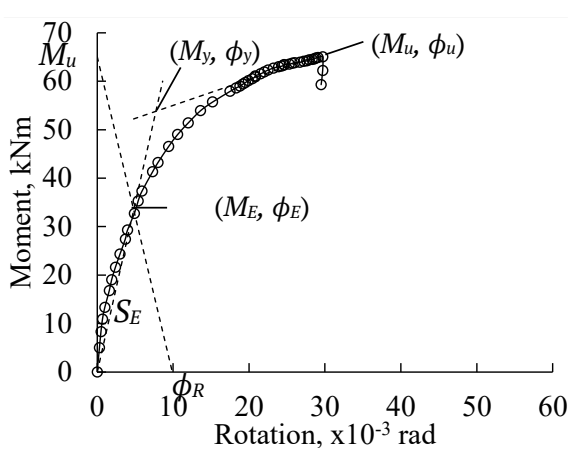

(c) Specimen PC3

Figure 6. Determining the properties of connection using beam-line method

The beam-line method proposed by Elliott (2002) was used to determine the properties of the specimens. The secant point $\left(M_{E}, \phi_{E}\right)$ was determined based on the characteristics of a perfectly rigid and pinned connection. A rigid connection is bound to have a moment capacity equivalent to the fixed-end moment of the beam, as shown in Equation (3). On the contrary, the rotation of a pinned connection is governed by the rotational limit of an RC beam, as shown in Equation (4).

$M_{R}=\frac{w L_{b}^{2}}{12}$

$\phi_{R}=\frac{w L_{b}^{3}}{24 E I_{b}}$

where $M_{R}$ is the fixed-end moment of the continuous beam $(\mathrm{kNm}), \phi_{R}$ is the allowable rotation of an RC beam (milli-rad), $w$ is the uniformly distributed load acting on the beam
$(\mathrm{kN} / \mathrm{m}), L_{b}$ is the beam span (m), $E$ is the elastic modulus of concrete $(\mathrm{kNm} / \mathrm{milli}-\mathrm{rad})$, and $I_{b}$ is the second moment of inertia on the beam crosssection $\left(\mathrm{m}^{4}\right)$.

Besides, assuming the ultimate moment capacity of the specimen, $M_{u}$ was equivalent to the fixedend moment of the beam, $M_{R}$, the allowable rotation of the connection, $\phi_{R}$ is as stated in Equation (5).

$\phi_{R}=\frac{M_{u} L_{b}}{2 E I_{b}}$

where $M_{u}$ is the ultimate moment capacity of the connection (kNm), $L_{b}$ is the effective span of beam (m), assumed to be $6 \mathrm{~m}$ (typical beam span), $E$ is the elastic modulus of the beam $\left(\mathrm{kN} / \mathrm{m}^{2}\right)$, which was obtained as $35 \mathrm{GPa}$ for a grade 40 (BS-EN 1992-1-1:2004) concrete, and $I_{b}$ is the second moment of inertia on the beam $\left(\mathrm{m}^{4}\right)$. 
The beam-line intercepted the $M-\phi$ curve at the secant point $\left(M_{E}, \phi_{E}\right)$. The gradient connecting the secant point with the Origin was considered the secant stiffness, $S_{E}$ (Equation (6)).

$S_{E}=\frac{M_{E}}{\phi_{E}}$

The secant stiffness line was further extended to the intercept with a best-fit straight line of the $M$ $\phi$ curve at the ultimate state to determine the yield point $\left(P_{y}, \phi_{y}\right)$ (Figure 6$)$. The properties of the connection were determined by using the Beam-Line Method, as shown in Table 7.

The first crack moment, $M_{i c}$, was discovered to be relatively equivalent to $1 / 5$ of the ultimate moment, $M_{u}$ (refer to the ratio of $M_{i c} / M_{u}$ reported in Table 8). However, before the first crack, the connection was in its best condition and had the highest degree of stiffness.

The secant moment, $M_{E}$ was conservatively considered as the designed strength of the connection, $M_{d}(\mathrm{Lim}, 2014)$. This was relatively 2 to 3 times equivalent to the first crack moment, $M_{\text {ic }}$ as well as approximately $29 \%$ to $61 \%$ of the ultimate moment, $M_{u}$ depending on the secant stiffness (Table 8). In general, the design moments, $M_{d}$ of the PC connections, were generally lower than their ultimate moments, $M_{u}$. This led to a sizeable unutilized connection strength between $M_{u}$ and $M_{d}$. When the $M_{u}$ and $\phi_{R}$ are similar, the unutilized strength of the connection can be reduced by increasing its stiffness, as shown in Figure 7.

Table 7. Test results

\begin{tabular}{lllllll}
\hline & $\begin{array}{l}\text { Rotation } \\
\text { limit, } \phi_{R}\left(10^{-3}\right. \\
\text { Rad })\end{array}$ & $\begin{array}{l}\text { Secant } \\
\text { moment, } M_{E} \\
(\mathrm{kNm})\end{array}$ & $\begin{array}{l}\text { Secant } \\
\text { rotation, } \phi_{E} \\
\left(10^{-3} \mathrm{rad}\right)\end{array}$ & $\begin{array}{l}\text { Secant } \\
\text { stiffness, } S_{E} \\
\left(\mathrm{kNm} / 10^{-3} \mathrm{rad}\right)\end{array}$ & $\begin{array}{l}\text { Yield moment, } \\
M_{y}(\mathrm{kNm})\end{array}$ & $\begin{array}{l}\text { Yield rotation, } \\
\phi_{y}\left(10^{-3} \mathrm{rad}\right)\end{array}$ \\
\hline Equation & $(5)$ & & & $(6)$ & & \\
\hline RC0 & 8.2 & 32.9 & 3.1 & 10.6 & 47.8 & 4.5 \\
PC0 & 8.6 & 25.4 & 4.7 & 5.4 & 47.6 & 8.8 \\
PC1 & 8.9 & 23.3 & 5.4 & 4.3 & 51.8 & 12.0 \\
PC2 & 9.6 & 28.2 & 5.3 & 5.3 & 49.0 & 9.2 \\
PC3 & 9.9 & 33.4 & 4.8 & 7.0 & 53.6 & 7.7 \\
PC4 & 9.7 & 18.3 & 6.9 & 2.7 & 42.4 & 16.0 \\
PC5 & 10.4 & 34.7 & 5.1 & 6.8 & 54.4 & 8.0 \\
PC6 & 8.8 & 27.4 & 4.7 & 5.8 & 51.3 & 8.8 \\
PC7 & 10.4 & 35.1 & 5.0 & 7.0 & 55.5 & 7.9 \\
PC8 & 9.8 & 33.5 & 4.7 & 7.1 & 52.0 & 7.3 \\
PC9 & 9.4 & 20.5 & 6.2 & 3.3 & 48.9 & 14.8 \\
\hline
\end{tabular}

Table 8. Performance ratio

\begin{tabular}{llllllllll}
\hline Specimen & $M_{i c} / M_{E}$ & $M_{i c} / M_{y}$ & $M_{i c} / M_{u}$ & $M_{E} / M_{u}$ & $M_{y} / M_{u}$ & $\phi_{E} / \phi_{R}$ & $\phi_{y} / \phi_{R}$ & $\phi_{u} / \phi_{R}$ & $\phi_{u} / \phi_{y}$ \\
\hline RC0 & 0.31 & 0.22 & 0.19 & 0.61 & 0.89 & 0.38 & 0.55 & 2.7 & 4.8 \\
PC0 & 0.45 & 0.24 & 0.20 & 0.45 & 0.84 & 0.55 & 1.02 & 5.3 & 5.2 \\
PC1 & 0.48 & 0.22 & 0.19 & 0.40 & 0.89 & 0.61 & 1.35 & 3.8 & 2.8 \\
PC2 & 0.49 & 0.28 & 0.22 & 0.45 & 0.78 & 0.55 & 0.96 & 4.1 & 4.3 \\
PC3 & 0.40 & 0.25 & 0.20 & 0.51 & 0.82 & 0.48 & 0.78 & 3.0 & 3.9 \\
PC4 & 0.43 & 0.18 & 0.12 & 0.29 & 0.67 & 0.71 & 1.65 & 5.4 & 3.3 \\
PC5 & 0.26 & 0.16 & 0.13 & 0.51 & 0.80 & 0.49 & 0.77 & 2.4 & 3.1 \\
PC6 & 0.49 & 0.26 & 0.23 & 0.47 & 0.89 & 0.53 & 1.00 & 3.1 & 3.1 \\
PC7 & 0.40 & 0.25 & 0.20 & 0.51 & 0.81 & 0.48 & 0.76 & 1.9 & 2.5 \\
PC8 & 0.44 & 0.28 & 0.23 & 0.52 & 0.81 & 0.48 & 0.74 & 2.9 & 3.8 \\
PC9 & 0.56 & 0.23 & 0.19 & 0.33 & 0.80 & 0.66 & 1.57 & 5.8 & 3.7 \\
\hline
\end{tabular}




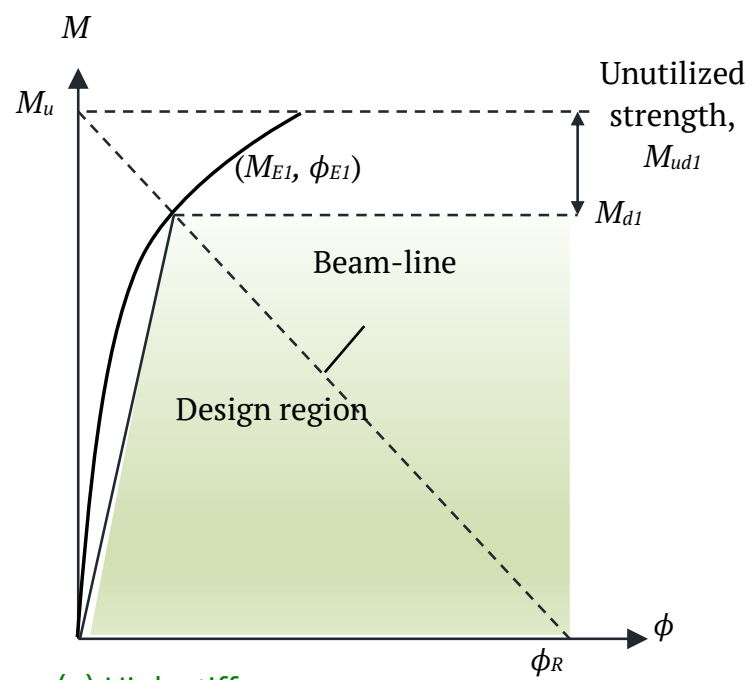

(a) High stiffness

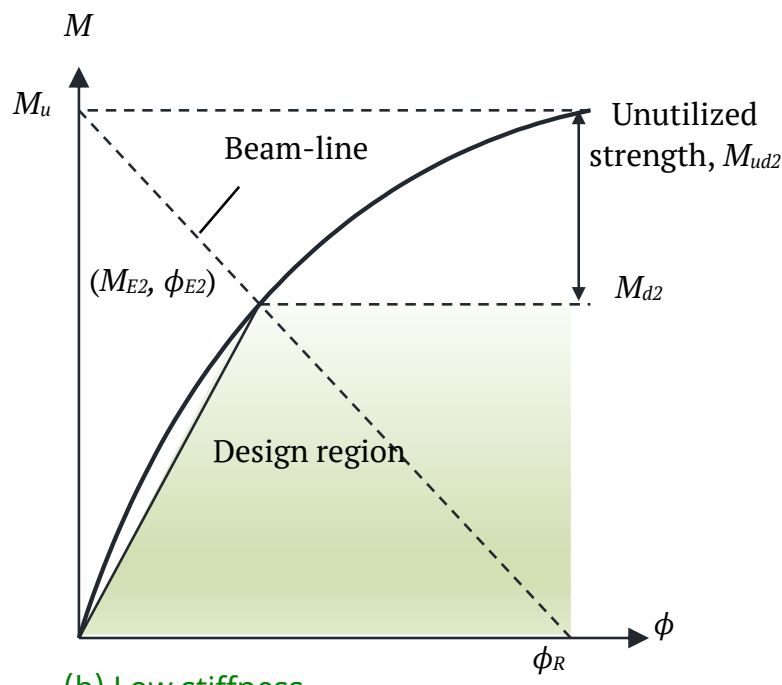

(b) Low stiffness

Figure 7. Effect of connection stiffness on the design strength

The yield point was an imaginary state where significant damages to the connection were expected to occur. It was not considered as the design load because (a) it fell above the $M-\phi$ curve, which is not achievable in reality, (b) it underestimated the instantaneous rotation of the connection, realized under the loads, and (c) its rotation occasionally exceeded the rotation limit of the beam $\left(\phi_{y} / \phi_{R} \geqslant 1.0\right.$, as shown in Table 8$)$.

\subsection{Classification of Connection}

Adopting the principles of Eurocode 3 (BS EN 1993-1-8:2005), a PC connection was classified by its stiffness and strength (Table 9).

Table 9. Classifications of connection based on stiffness and strength

\begin{tabular}{lll}
\hline Classification & Stiffness & Requirement \\
\hline $\begin{array}{l}\text { Stiffness } \\
\text { (kNm/10-3 }\end{array}$ & Pinned & $\begin{array}{l}S_{E} \leq \frac{0.5 E I_{b}}{L_{b}} \\
\text { rad) }\end{array}$ \\
& Semi-rigid & $\frac{0.5 E I_{b}}{L_{b}}<S_{E}<\frac{k_{b} E I_{b}}{L_{b}}$ \\
& Rigid & $S_{E} \geq \frac{k_{b} E I_{b}}{L_{b}}$ \\
\hline $\begin{array}{l}\text { Strength } \\
\text { (kNm) }\end{array}$ & Pinned & $M_{d} \leq 0.25 M_{R d}$ \\
& Partial & $0.25 M_{R d} \leq M_{d} \leq M_{R d}$ \\
& strength & \\
& strength & $M_{d} \geq M_{R d}$ \\
\hline
\end{tabular}

E is the modulus of elasticity of concrete $\left(\mathrm{kN} / \mathrm{m}^{2}\right), I_{b}$ is the second moment of inertia $\left(m^{4}\right), L_{b}$ is the beam span (m), $k_{b}$ is equal to 8 and 25 for the braced and unbraced system respectively, $M_{d}$ is the designed strength of the connection $(\mathrm{kNm}), M_{R d}$ is the moment strength of the members $(\mathrm{kNm})$.

The moment strength of a member, $M_{R d}$, was considered to be the smaller value of the column, $M_{R d, c}$, and the beam, $M_{R d, b}$ (Equation 7), determined using Equation 8 as the moment strength of an RC member.

$M_{R d}=\min \left(M_{R d, c}, M_{R d, b}\right)$

$M=\frac{f_{y k} z A_{s}}{\gamma_{c}}$

where $f_{y k}$ is the specified yield strength of the reinforcement bars, $\gamma_{c}$ is the partial factor of safety of steel, $A_{s}$ is the cross-sectional area of the bar, and $z$ is the lever arm of the stress block diagram $(\mathrm{mm})$, which were all assumed as 500 $\mathrm{N} / \mathrm{mm}^{2}, 1.15,402 \mathrm{~mm}^{2}$ for $2 \mathrm{~T} 16$, and $0.95 d$ respectively. In general, the connection was considered to be semi-rigid with partial strength, as shown in Table 10. 
Table 10. Classification of the connection by stiffness

\begin{tabular}{lllllllll}
\hline Classification & \multicolumn{3}{c}{ Stiffness } \\
\hline Specimen & $\begin{array}{l}\text { Pinned } \\
\left(\mathrm{kNm} / 10^{-3}\right. \\
\mathrm{rad})\end{array}$ & $\begin{array}{l}\text { Braced } \\
\text { frame } \\
\left(\mathrm{kNm} / 10^{-3}\right. \\
\mathrm{rad})\end{array}$ & $\begin{array}{l}\text { Unbraced } \\
\text { frame } \\
\left(\mathrm{kNm} / 10^{-3}\right. \\
\mathrm{rad})\end{array}$ & $\begin{array}{l}\text { Secant } \\
\text { stiffness, } S_{E} \\
\left(\mathrm{kNm} / 10^{-3}\right. \\
\mathrm{rad})\end{array}$ & $\begin{array}{l}\text { Stass } \\
\text { Clrength }\end{array}$ & $\begin{array}{l}\text { Design } \\
\text { moment, } \\
M_{d}(\mathrm{kNm})\end{array}$ & $M_{d} / M_{R d}$ & Class \\
\hline PC0 & 1.6 & 26.3 & 82.0 & 5.4 & $\mathrm{~S}$ & 25.4 & 0.73 & $\mathrm{P}$ \\
PC1 & 1.6 & 26.3 & 82.0 & 4.3 & $\mathrm{~S}$ & 23.3 & 0.67 & $\mathrm{P}$ \\
PC2 & 1.6 & 26.3 & 82.0 & 5.3 & $\mathrm{~S}$ & 28.2 & 0.81 & $\mathrm{P}$ \\
PC3 & 1.6 & 26.3 & 82.0 & 7.0 & $\mathrm{~S}$ & 33.4 & 0.96 & $\mathrm{P}$ \\
PC4 & 1.6 & 26.3 & 82.0 & 2.7 & $\mathrm{~S}$ & 18.3 & 0.53 & $\mathrm{P}$ \\
PC5 & 1.6 & 26.3 & 82.0 & 6.8 & $\mathrm{~S}$ & 34.7 & 1.00 & $\mathrm{~F}$ \\
PC6 & 1.6 & 26.3 & 82.0 & 5.8 & $\mathrm{~S}$ & 27.4 & 0.79 & $\mathrm{P}$ \\
PC7 & 1.6 & 26.3 & 82.0 & 7.0 & $\mathrm{~S}$ & 35.1 & 1.01 & $\mathrm{~F}$ \\
PC8 & 1.6 & 26.3 & 82.0 & 7.1 & $\mathrm{~S}$ & 33.5 & 0.97 & $\mathrm{P}$ \\
PC9 & 1.6 & 26.3 & 82.0 & 3.3 & $\mathrm{~S}$ & 20.5 & 0.59 & $\mathrm{P}$ \\
\hline
\end{tabular}

${ }^{*} E_{b}=35000000 \mathrm{kN} / \mathrm{m}^{2}, I_{b}=0.000562500000 \mathrm{~m}^{4}, L_{b}=6 \mathrm{~m} ;{ }^{2}$ Classification: R - Rigid, S - Semi-rigid, P - Pinned; ${ }^{3} M_{R d, b}$ $=40.4 \mathrm{kNm}, M_{R d, c}=34.7 \mathrm{kNm}, M_{R d}=34.7 \mathrm{kNm}$ (Equation 7$) ;{ }^{4} \mathrm{~F}-$ Full-strength $\left(M_{d} / M_{R d} \geqslant 1.0\right), \mathrm{P}-$ Partial-strength $\left(0.25<M_{d} / M_{R d}<1.0\right)$, Pn - Pinned $\left(M_{d} / M_{R d} \leqslant 0.25\right)$

\subsection{Parametric Response}

The PC connection generally possessed a lower degree of stiffness than the RC. This was attributed to (a) the relative movements of the cold joints between the components and (b) the poor bending resistance of the steel endplate, both of which led to a larger instantaneous rotational deformation under the load.

Nevertheless, the PC connection had a higher ultimate moment capacity, $M_{u}$, than the RC due to (a) the extensive usage of the steel components and (b) the enhanced SHS hidden corbel. The PC connection without hidden corbel, PC0, had a $M_{u}$ $5.6 \%$ higher than the RC0. Meanwhile, those with hidden corbel (PC1 to PC9) had a $M_{u}$ of approximately $7.6 \%$ to $27.3 \%$ higher than the RC0. Additionally, both the steel endplate and hidden corbel offered bending resistance to the connection, as shown in Figure 8.

The ultimate moment, $M_{u}$ of the connection increased as the embedded lengths of SHS hidden corbel in the column and beam increased. Furthermore, when the embedded length in the column increased from $75 \mathrm{~mm}$ to $150 \mathrm{~mm}, M_{u}$ increased to $6.9 \%$. On the contrary, when the one in the beam increased from $200 \mathrm{~mm}$ to $300 \mathrm{~mm}$, the $M_{u}$ increased to $18.3 \%$. The longer the embedded length, the larger the bearing area for the hidden corbel to effectively transfer stresses from the beam to the column.

The grout in the hidden corbel caused an increase in the ultimate moment of the connection. Nevertheless, the connection with $20 \mathrm{~N} / \mathrm{mm}^{2}$ grout in the hidden corbel (PC8) resulted in a higher $M_{u}$ of $4.7 \%$ compared to that without grout (PC9). However, as the grout strength increased from $20 \mathrm{~N} / \mathrm{mm}^{2}$ to $40 \mathrm{~N} / \mathrm{mm}^{2}, M_{u}$ increased by only $0.9 \%$ (PC3 and PC8). Therefore, the grout is weak in respect to flexural bending. Its main function was to prevent the SHS hidden corbel from undergoing lateral deformation that affected the bending resistance of the connection.

\subsection{Failure Mode}

The failure mode of the specimens (Figure 9) is shown in Table 11. Generally, the load vertically displaced the free end of the beam, leading to the rotational deformation of the connection. The first crack occurred at the cold joint between the PC beam and the steel endplate. Afterward, it developed on the beam's upper surface, which is referred to as the flexural crack. In addition, it was later discovered at the compressive region of the 
connection and eventually developed into diagonal and peripheral cracks that passed through and by the SHS hidden corbel, respectively (Figure 9). Many specimens endured spalling at the tension region of the beam, while some experienced crushing at the compressive area. The steel endplate bent considerably, which subsequently led to the dislocation of the steel stud welded to it, thereby resulting in the spalling of concrete.

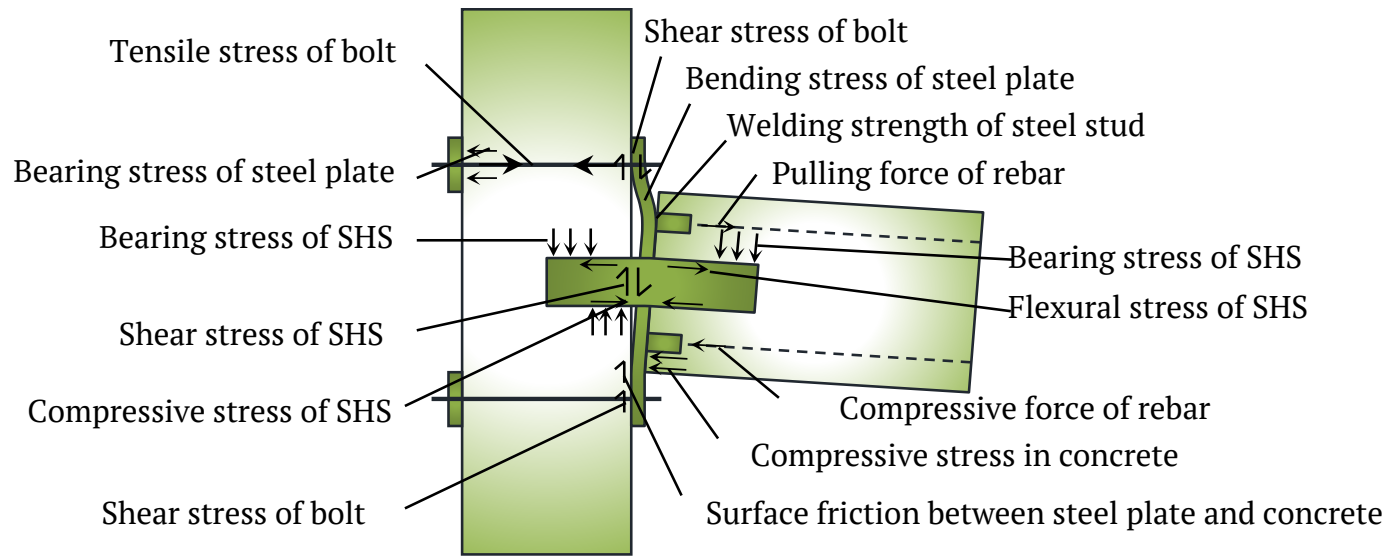

Figure 8. Load resisting mechanism of the connection

Table 11. Failure modes of the specimens

\begin{tabular}{|c|c|c|c|c|c|c|c|c|}
\hline \multirow[b]{2}{*}{ Specimen } & \multicolumn{5}{|c|}{ Beam } & \multicolumn{2}{|r|}{ Joint } & \multirow{2}{*}{\begin{tabular}{l}
\multicolumn{1}{c}{ Column } \\
Diagonal \\
tensile crack
\end{tabular}} \\
\hline & Crushing & Spalling & $\begin{array}{l}\text { Diagonal } \\
\text { crack }\end{array}$ & $\begin{array}{l}\text { Peripheral } \\
\text { crack }\end{array}$ & $\begin{array}{l}\text { Flexural } \\
\text { crack }\end{array}$ & $\begin{array}{l}\text { Bended } \\
\text { endplate }\end{array}$ & $\begin{array}{l}\text { Vertical } \\
\text { tearing crack }\end{array}$ & \\
\hline RC0 & & & & & $\mathrm{L}$ & & $\mathrm{H}$ & $\mathrm{L}$ \\
\hline PC0 & $\mathrm{H}$ & $\mathrm{L}$ & & & $\mathrm{L}$ & $\mathrm{H}$ & & \\
\hline PC1 & $\mathrm{L}$ & $\mathrm{H}$ & M & & & $\mathrm{H}$ & & $\mathrm{L}$ \\
\hline PC2 & & M & $\mathrm{H}$ & & & $\mathrm{H}$ & & \\
\hline PC3 & & M & $\mathrm{H}$ & M & & $\mathrm{H}$ & & L \\
\hline PC4 & $\mathrm{H}$ & $\mathrm{H}$ & & $\mathrm{H}$ & & $\mathrm{H}$ & & $\mathrm{L}$ \\
\hline PC5 & & & & $\mathrm{H}$ & & M & & M \\
\hline PC6 & $\mathrm{H}$ & M & $\mathrm{H}$ & & & M & & M \\
\hline PC7 & $\mathrm{H}$ & $\mathrm{L}$ & & $\mathrm{H}$ & & M & & M \\
\hline PC8 & M & $\mathrm{M}$ & $\mathrm{H}$ & L & & M & & $\mathrm{H}$ \\
\hline PC9 & & $\mathrm{H}$ & & M & & $\mathrm{H}$ & & $\mathrm{L}$ \\
\hline
\end{tabular}

"Severity rating based on visual observation: $\mathrm{H}$ - high, $\mathrm{M}$ - moderate, $\mathrm{L}$ - Low

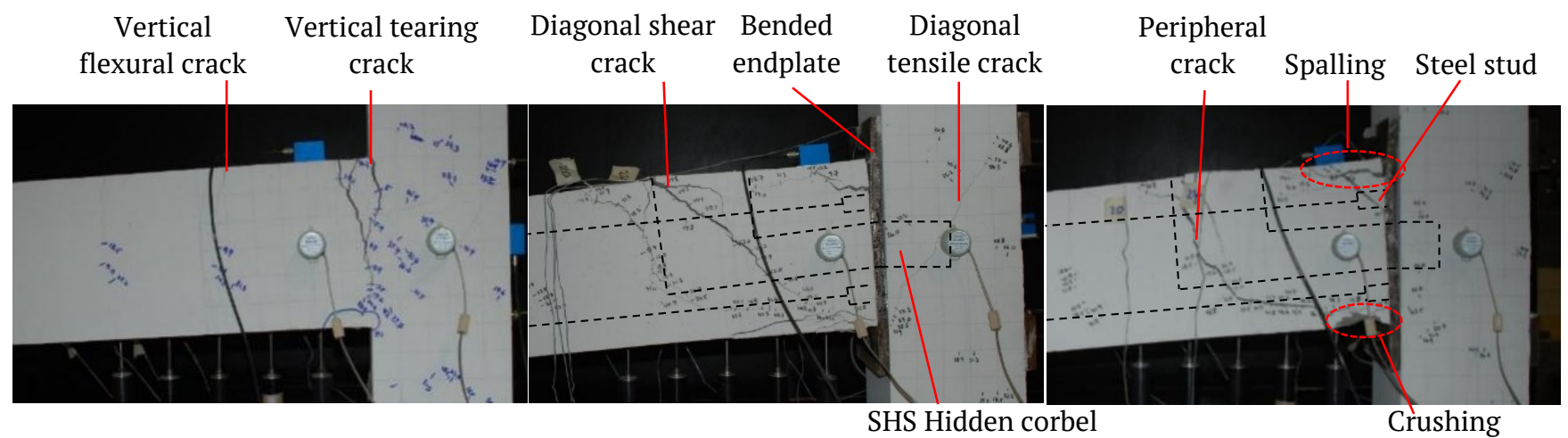
(a) RCO
(b) $\mathrm{PC} 3$
(c) PC4

Figure 9. The typical failure mode of the connection 
The responses of the connected components under the load are reported as follows (refer to Figure 8)

a) The beam rotation generated bearing stress which acted on the SHS hidden corbel, thereby leading to flexural load.

b) The pulling force of the top reinforcement bar generated bending and tensile stress in the steel endplate and bolts, respectively.

c) The rotational movement of the beam triggered the compressive stress in the bottom reinforcement bars and the concrete. This subsequently led to the frictional resistance between the steel endplate and the concrete.

d) The shear resistance of the bolts and the SHS hidden corbel resisted the vertical load. This further prevented the beam from displacing vertically.

Based on the load resisting mechanism, the capacity of the connection tended to be governed by (a) the tensile strength of the bolt, (b) the bending strength of the endplate, (c) the bending strength of the SHS, (d) the welding strength of the steel stud on the endplate, (e) the pullout strength between the top reinforcement bar and the steel stud and (f) the crushing strength of the concrete at the compressive region, whichever was weaker. In the circumstance that the connection was stronger than the beam and column, the RC member shall govern the load capacity.

The PC connections were generally stronger, as proven by the severe diagonal and peripheral cracks on the beam. Therefore, specimens PC0 to PC9 generally generated a higher ultimate moment, $M_{u}$, than the RC0. However, the significant bending deformation of the steel endplate had caused the connection to experience large rotational deformation with poor stiffness. This subsequently led to poor design strength of the connection over the ultimate load. Therefore, to improve the design strength, the effective second moment of inertia of the steel endplate in resisting the bending deformation needs to be increased, as shown in Figure 10.

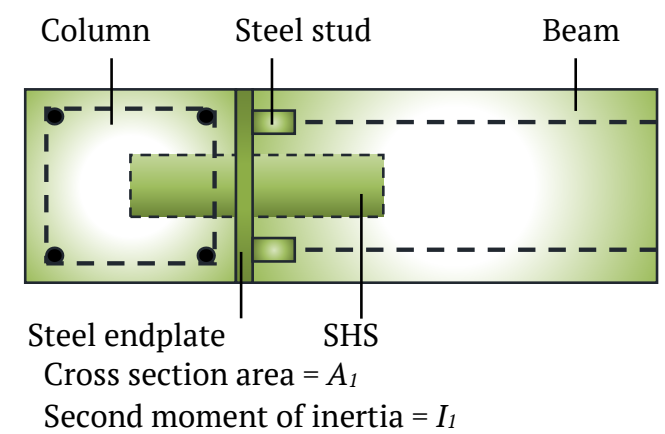

(a) Original design

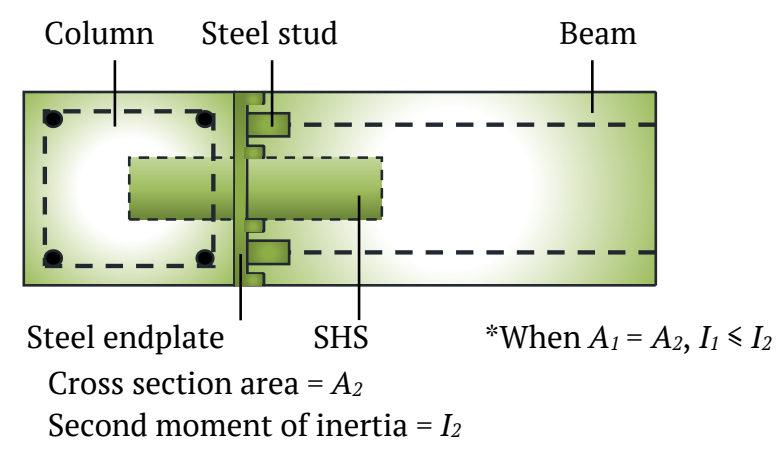

(b) New design

Figure 10. Comparison of the second moment of inertia of the steel endplate

\section{FEASIBILITY EVALUATION}

The feasibility of the PC connection was evaluated based on the following assessment criteria

a) C1: The moment strength of the PC connection was comparable to the RC. Therefore, both the ultimate strength ratio, $R_{m, u}$, and the design strength ratio, $R_{m, d}$, need to be relatively 1.0 .

$$
\text { i. } \quad R_{m, u}=\frac{M_{u, i}}{M_{u, c}} \geq 1.0
$$

where $M_{u, i}$ and $M_{u, c}$ are the ultimate moment of PC and RC connections respectively $(\mathrm{kNm})$.

$$
\text { ii. } \quad R_{m, d}=\frac{M_{d, i}}{M_{d, c}} \geq 1.0
$$

Besides $M_{d, i}$ and $M_{d, c}$ are the design moment of PC and RC connections respectively $(\mathrm{kNm})$.

b) C2: The connection needs to be ductile for survival purposes. Therefore, the ductility ratio, $R_{d c}$, has to be approximately 4.0 in the low-moderate seismic regions (Soudki, 1994; Ling et al., 2017). 
$R_{d c}=\frac{\phi_{u}}{\phi_{d}} \geq 4.0$

where $\phi_{u}$ is the rotation of connection at the ultimate state (milli-rad) and $\phi_{d}$ is the designed rotation of the connected beam (milli-rad)

c) C3: The connection need not fail earlier than the beam. Therefore, the ultimate rotation of the connection has to be greater than the allowable rotation of the beam, presumably 3 times more.

$R_{r}=\frac{\phi_{u}}{\phi_{R}} \geq 3.0$

d) C4: The design moment should not be too low compared to the ultimate moment in order to ensure that the connection is efficiently utilized. The design ratio, $R_{d}$, needs to be relatively 0.5 .

$R_{d}=\frac{M_{d}}{M_{u}} \geq 0.5$

where $M_{d}$ and $M_{u}$ are the design $(\mathrm{kNm})$, and ultimate moments of the connection $(\mathrm{kNm})$, respectively.

e) C5: In respect to the complexity in predicting the beam rotation, as the SHS hidden corbel of the connection tends to have altered (i.e. shortened) the effective length of the beam in computing $\phi_{R}$, some allowances may be required to ensure the rotation limit is not exceeded. The designed rotation is preferably less than $50 \%$ of the allowable rotation.

$R_{a}=\frac{\phi_{d}}{\phi_{R}} \leq 0.5$

where $\phi_{d}$ is the design rotation of connection (milli-rad), and $\phi_{R}$ is the rotation limit (milli$\mathrm{rad})$

The feasibility evaluation of the connection is shown in Table 12 . The connections were considered feasible only when all the assessment criteria were fulfilled.

Based on the evaluation, specimen PC3 was discovered to be feasible for PC structure. Irrespective of the fact that it did not have the largest moment capacity, however this specimen performed relatively well in various aspects. The second-best option was the PC8, which had satisfied 5 out of 6 criteria. The non-compliance in criteria C3 $\left(R_{r}=2.9\right)$ was rather close to the requirement, which is 3.0.

The main difference between specimens PC3 and PC 8 was their grout strengths of $40 \mathrm{~N} / \mathrm{mm}^{2}$ and 20 $\mathrm{N} / \mathrm{mm}^{2}$, respectively. This shows the need to have the SHS hidden corbel filled with grout, although this does not necessarily require high strength.

Table 12. Classification of connection by the strength

\begin{tabular}{|c|c|c|c|c|c|c|c|c|}
\hline Criteria & C1(i) & C1(ii) & C2 & C3 & $\mathrm{C} 4$ & C5 & \multirow{4}{*}{ Score ${ }^{* 1}$} & \multirow{4}{*}{ Feasible $^{* 2}$} \\
\hline Ratio & $R_{m, u}$ & $R_{m, d}$ & $R_{d c}$ & $R_{r}$ & $R_{d}$ & $R_{a}$ & & \\
\hline Equation & (9) & $(10)$ & $(11)$ & $(12)$ & $(13)$ & $(14)$ & & \\
\hline Requirement & $\geqslant 1.0$ & $\geqslant 1.0$ & $\geqslant 4.0$ & $\geqslant 3.0$ & $\geqslant 0.5$ & $\leqslant 0.5$ & & \\
\hline PC0 & 1.06 & 0.77 & 9.8 & 5.3 & 0.45 & 0.55 & $3 / 6$ & $\mathrm{~N}$ \\
\hline PC1 & 1.08 & 0.71 & 6.2 & 3.8 & 0.40 & 0.61 & $3 / 6$ & $\mathrm{~N}$ \\
\hline PC2 & 1.17 & 0.86 & 7.5 & 4.1 & 0.45 & 0.55 & $3 / 6$ & $\mathrm{~N}$ \\
\hline PC3 & 1.21 & 1.02 & 6.2 & 3.0 & 0.51 & 0.48 & $6 / 6$ & $\mathrm{Y}$ \\
\hline PC4 & 1.18 & 0.56 & 7.6 & 5.4 & 0.29 & 0.71 & $3 / 6$ & $\mathrm{~N}$ \\
\hline PC5 & 1.27 & 1.05 & 4.8 & 2.4 & 0.51 & 0.49 & $5 / 6$ & $\mathrm{~N}$ \\
\hline PC6 & 1.08 & 0.83 & 5.9 & 3.1 & 0.47 & 0.53 & $3 / 6$ & $\mathrm{~N}$ \\
\hline PC7 & 1.27 & 1.07 & 3.9 & 1.9 & 0.51 & 0.48 & $4 / 6$ & $\mathrm{~N}$ \\
\hline PC8 & 1.20 & 1.02 & 6.0 & 2.9 & 0.52 & 0.48 & $5 / 6$ & $\mathrm{~N}$ \\
\hline PC9 & 1.14 & 0.62 & 8.8 & 5.8 & 0.33 & 0.66 & $3 / 6$ & $\mathrm{~N}$ \\
\hline
\end{tabular}

${ }^{{ }^{1}}$ Score - number of criteria fulfilled / total number of criteria; ${ }^{2} \mathrm{Y}$ - Feasible, $\mathrm{N}$ - Not feasible 


\section{CONCLUSION}

In this study, an experimental test was conducted on eleven full-scale $\mathrm{T}$-subframe specimens to investigate the behaviour of precast concrete beam-to-column connection in respect to SHS hidden corbel. The mechanical properties of the connections were determined and classified based on the beam-line method and the Eurocode 3 , respectively. The connections were classified semi-rigid and partial strength.

Due to the steel components, the PC connection offered an approximately $6 \%$ to $27 \%$ higher ultimate moment than the RC. However, due to low stiffness, the design strength of the PC connection was generally lower than the RC.

The SHS hidden corbel contributed to the moment resistance of the connection. Its embedded length in the column and the beam increased the moment strength of the connection. The grout infill was discovered to strengthen the hidden corbel, although the increasing strength of the connection was minimal.

Furthermore, excessive bending deformation of the steel endplate was identified to be the root cause of the low stiffness and design strength of the connection, which subsequently led to the ineffective utilization of the moment capacity. The steel endplate may be modified to increase the second moment of inertia for higher efficiency of the connection design.

The feasibility of the connection was evaluated in various aspects, namely the strength, ductility, serviceability, and design tolerance. The evaluation was carried out based on relative comparison among the test specimens. In addition, specimen PC3 was discovered to fulfill all the evaluation criteria and was therefore considered feasible.

\section{DISCLAIMER}

The authors declare no conflict of interest.

\section{AVAILABILITY OF DATA AND MATERIALS}

All data are available from the author.

\section{ACKNOWLEDGMENTS}

The authors are grateful to the Ministry of Higher Education, Vot 78013, for the Research Grants provided to carry out this research.

\section{REFERENCES}

BS-EN 1992-1-1:2004, 2004. Eurocode 2: Design of concrete structures - Part 1-1: General rules and rules for buildings.

BS EN 1993-1-8:2005, 2005. Eurocode 3: Design of steel structures - Part 1-8: Design of joints.

Choi, H. K., Choi, Y. C. \& Choi, C. S., 2013. Development and Testing of Precast Concrete Beam-to-Column Connections. Engineering Structures, 56, pp 1820-1835.

Elliott, K. S., 2002. Precast Concrete Structure, Boston: Butterworth-Heinemann.

Jaspart, J. P., 1996. Structural Connections: Experimental as Design Tool. Seminar Structural Assessment: The Role of Large and Full Scale Testing. City University, London

Lim, J. H., 2014. Experimental Behaviour of Exterior Hybrid Precast Concrete Beam-to-Column Connections Subjected to Monotonic Load. PhD Thesis, Universiti Teknologi Malaysia.

Lin, F. \& Zhao, P., 2020. Behavior of Grouted Sleeve Splice for Steel Profile under Tensile Loadings. Materials, 13(9), 2037.

Ling, J. H., Abd. Rahman, A. B., Ibrahim, I. S. \& Abdul Hamid, Z. 2017. An Experimental Study of Welded Bar Sleeve Wall Panel Connection under Tensile, Shear, and Flexural Loads. International Journal of Concrete Structures and Materials, 11, pp 525-540.

Lu, Z., Huang, J., Li, Y., Dai, S., Peng, Z., Liu, X. \& Zhang, M., 2019. Mechanical Behaviour of Grouted Sleeve Splice under Uniaxial Tensile Loading. Engineering Structures, 186, pp 421-435.

Soudki, K. A., 1994. Behaviour of Horizontal Connections for Precast Concrete Load-bearing Shear Wall Panels Subjected to reversed Cyclic Deformations. PhD thesis, University of Manitoba. 
Zheng, Y., Guo, Z., Guan, D. \& Zhang, X., 2018. Parametric Study on a Novel Grouted Rolling Pipe Splice for Precast Concrete Construction.
Construction and Building Materials, 166, pp 452463. 
[This page is intentionally left blank] 